\title{
CATALYZING THE SOCIO-LEGAL SPACE FOR ARMED CONFLICT: LAND AND LEGAL PLURALISM IN PRE-WAR LIBERIA
}

\author{
Jon D. Unruh \\ McGill University
}

\section{Introduction}

While acute land rights problems are recognized as an important catalyst for armed conflict, precisely what the structural-tenurial catalyzing process comprises, remains unexamined. Aggressively confrontational social relations involving land rights emerge from a pluralistic socio-legal space in which the component parts come to be set against one another. The result is an aggravated accumulation of competition, inequity, confrontation, grievance, resentment, and animosity, with no institutional way to manage these across opposing components. This paper makes the argument that while the interface between customary and statutory land tenure is a problem in many parts of Africa, the way such legal pluralism is handled can be a significant contributor to armed conflict. While many countries contain some variation of a pluralistic customary - statutory tenure divide, it is treated and managed in a wide variety of ways. Liberia's approach prior to its civil war (occurring in two phases, 1989 - 1996 and 1999 - 2003) was to engage in a form of divisive pluralism in the country's constitutional, social, political, economic, and institutional life from the beginning of its history as a country (Richards et al 2004). The distinctions made between 'civilized' and 'uncivilized' peoples, laws, customs, culture, and importantly land tenure, had a pervasive, long-term, and polarizing influence in the interaction of different sets of land rights. Ultimately the tenurial socio-legal space in Liberia comprised an extremely aggravated interaction which led to an agrarian crisis constituting the wholesale failure of rural institutions; a crisis which Richards et al (2004) articulately describe.

(C) Copyright 2009 - Jon Unruh 
It is widely acknowledged that land problems were a primary factor in the cause and maintenance of the war in Liberia and the ensuing crisis (e.g. GRC 2007; Bruce 2007; Richards 2005; Sawyer 2005; ICG 2006; Banks 2007; Kollie 2006; Wily 2007; Unruh 2009). Indeed Bruce (2007) notes that early battles over land erupted due to fundamental differences in conceptions of land ownership between the Americo-Liberian settlers and indigenous inhabitants as early as 1822, the year Liberia was founded. Riddell and Dickerman (1986, 102), citing Liebnow, note that during the Doe regime (1980 - 1990) "[1]and tenure is at the heart of rural discontent." Subsequent to the war, the Liberian Governance Reform Commission concluded that access to land was a root cause of the armed conflict (GRC 2007). However how this 'root cause' came about has not yet been examined adequately.

This article describes how the socio-legal space with regard to land tenure was created in Liberia, and how interaction within this space was a primary catalyst for the war. The interaction between a contradictory and confused set of formal land laws, strongly held customary concepts about land, discriminatory 'state sponsored' customary law, and numerous ad hoc land and property norms connected to instability, constituted the socio-legal space within which extremely volatile tensions came to reside. With no legitimate way to deactivate these tensions, they became pervasive and then explosive. Subsequent to a description of the fieldwork and the legislation examined, this paper describes the background to the Liberian case, defines the socio-legal space by briefly specifying the different bodies of formal and informal law, and then analyzes the relevant patterns of socio-legal interaction.

\section{Data Gathering}

The research for this analysis comprised a series of individual and group interviews and focus group discussions in Liberia totaling 210 people in the months of December 2006 and February 2007, as part of land tenure policy reform work led by the Liberian Governance Reform Commission. Those interviewed included smallholder farmers, large landholders, ministry officials, university researchers, NGOs, lawyers, UN personnel, commercial agriculture associations, bilateral and multilateral donors, international legal and development organizations, and a former President of the country. The laws analyzed include: The Constitution 1986, The Public Lands Law 1956, The Local Government Law 1972, Laws and Regulations Governing the Hinterland revised 2001, Rules and Regulations Governing Local Government Officials revised 2005, ${ }^{1}$ The Wildlife and National Parks Act 1987, and

1 The Laws and Regulations Governing the Hinterland and the Local Government Officials Law were only very slightly revised toward the end of the war, and thus continue to exist largely in their prewar states. 
The Natural Resources Law 1999. As well an examination of the relevant academic, Liberian government, NGO, legal, and donor literature took place.

\section{Background}

Former American slaves were settled on the Liberian coast beginning in the $19^{\text {th }}$ century, and a statutory system of land tenure was established in areas under their control. The settler society was exclusive, and resided within an array of indigenous African coastal communities. These indigenous communities possessed land tenure systems that held land to be inalienable. Nevertheless settlers interacting with local communities pursued alienation of land (instead of use) made possible by a mix of violent conflict and alliance-making (Sawyer 2005). Settler acquisition of lands was supported by a variety of (largely received) laws, including an early constitution (Sawyer 2005; Wily 2007). While indigenous lands on the coast appear to have been purchased, in the 'hinterland' indigenous land was acquired through an extension of the 1847 constitution into the interior, together with its enabling laws (Wily 2007). Indigenous customary law, based on usufruct rights, continued in areas inhabited by local communities and administered as provinces by the Liberian state. The initial decades of the $20^{\text {th }}$ century saw often brutal subjugation of parts of the countryside, with the resulting tensions between the settlers and indigenous inhabitants reflected in longstanding land issues. When the provinces became counties in the midtwentieth century, the customary tenure system continued, and parts of it became 'sponsored' (meaning officialized, altered and used by the state), while other parts were neglected or declared illegal (GRC 2007).

Indigenous smallholder claim and use of land was the tenurial focus of most of the Liberian interior until Firestone was established as the first rubber concession in the 1920s (GRC 2007). The statutory tenure system then became the legal basis for the derivation of concessions for rubber, timber, and minerals throughout the country. Such concessions were often foreign-controlled private commercial farms. Over time, increasing areas of rural Liberia were transferred from the customary system to the statutory tenure system by the acquisition of land deeds by Americo-Liberians using state sponsored customary law through chiefs (GRC 2007). Enourmous land acquisitions deprived local inhabitants of access to agricultural land, sacred groves, shrines, and tree crops (Bruce 2007). Rampant land appropriation and land speculation eventually evolved into sources of acute uncertainty, grievance and conflict. By the outbreak of the civil war in 1990, the legal mechanisms for acquiring land deeds, especially in areas under forms of customary tenure, was a seriously contentious and volatile issue (Unruh 2009; GRC 2007). This included mechanisms for acquiring rights to lands which contained valuable timber and alluvial diamond and gold deposits which fueled the conflict (UNEP 2004). 


\section{The Tenurial Legal Fields: Formal, Customary, 'State Sponsored Customary', and ad hoc Norms}

This section briefly describes the primary components which comprised the sociolegal space regarding land tenure in pre-war Liberia. The functioning and interaction of these components within this space is then examined in the subsequent section.

\section{Formal land law in Liberia}

Liberia's statutory law resides within the Anglo-American common law legal tradition. As a new country in the early 1800 s Liberia 'received' a complex body of statutory land law from the United States initially derived in England and modified over decades to suit American social reality (Bruce 2007). Particularly relevant in the Liberian context, is that American law regarding land and indigenous people in the early 1800s was extremely discriminatory in its treatment of land rights (Unruh 2002). The degree and effectiveness of the subsequent modification of this law by Liberian legal decisions and statutes in order to serve Liberian reality, was profoundly inadequate. There was also a great deal of confusion regarding the overall status and application of Liberian derived polices and laws regarding land and property. Those that existed were unclear, often contradictory, lacked effective implementing regulations, and for most of the country's history were very dated and so did not effectively engage contemporary Liberia. ${ }^{2}$ Bruce (2007) notes that the lack of access to court decisions and laws in Liberia before the war was so severe that it constituted a legal vacuum.

Prior to the conflict there existed five primary statutory laws in Liberia that defined formal land rights and the relationship (from a statutory perspective) between formal and customary tenure systems. While two of these laws were central to how statutory land rights worked, and contained articles that pertained to the interface between statutory and customary tenure (The Constitution 1986, The Public Lands

\footnotetext{
2 Much in Liberian statutory law regarding land, prior to the war, reflected colonial approaches that did not resonate with contemporary social realities (Bruce 2007), even within the formal tenure system. For example the Laws and Regulations for Governing the Hinterland is almost the same in both structure and language to other Anglophone African colonies in West Africa that date from the 1930s and 1940s, which have in those countries been abandoned and revised, while Liberia has maintained them (ICG 2006).
} 
Law 1956), three others were focused almost entirely on interaction between the formal and customary sectors (Local Government Law 1972, Laws and Regulations Governing the Hinterland revised 2001, Rules and Regulations Governing Local Government Officials revised 2005). Two additional laws were also relevant to the interface between tenure systems, the Wildlife and National Parks Act 1987, and the Natural Resources Law 1999.

In the period leading up to the war there was significant ambiguity, confusion, and contradiction regarding which laws were to have been applied in which cases and how, particularly with regard to the granting of concessions and resolution of disputes. As well, the court system constituted a problematic and pluralistic set of institutions for solving land and property disputes, and there existed an extremely confused variety of procedures for dispute resolution depending on the actors, the context, and the issue at hand. The overall perspective of statutory land-related laws, beginning with the Constitution, was that the customary inhabitant of Liberia was subject to statutory laws, while not being able to participate in them-meaning they possessed little in the way of constitutional rights, resulting in an inability to hold land under statutory law. At the same time Americo-Liberians were not subject to customary laws. This set the formal tenure system against the customary system, which the government attempted to resolve by the delimitation of 'state sponsored customary law', but which instead created a third tenure system.

\section{Customary legal concepts about land}

Customary law in Liberia and land tenure in particular is exceptionally poorly documented and studied, as are how any customary tenure cases might have been handled by statutory courts, and the interactions between customary and civil authorities (Bruce 2007; ICG 2006). Allot (1967), writing during one of the brief periods when the Liberian Law Journal was publishing, noted that "[p]ractically no cases involving the substantive rules of customary law have ever reached the Liberian law reports". In particular the issues of when to apply customary or statutory law and the conflict of laws "has received little if any legislative or judicial attention" (Allot 1967). As well McCarthy's (2007) review of Liberian Supreme Court cases found almost none mentioning customary land law. Bruce $(2007,28)$ notes that ' $[t]$ here is perhaps no country in Africa where less is known of customary systems of land tenure". Thus this section of the article instead of describing customary land law in Liberia, describes from the fieldwork two broad fundamental customary legal concepts, or postulates regarding land, that are not a set of customary laws per se, but are nonetheless very strongly held and defended, and are what customary tenure laws are based on. 
The first concept is that customary group connection to specific land areas in Liberia is based on the idea of early and later arrivals. The distinction between groups (including their descendents) who arrived first in certain areas of the country, and the chronology of the founding of particular settlements, versus those who arrived later, is a primary customary land concept that serves as a foundation for other customary legal perscriptions. Widely practiced in West Africa (e.g. MarshallFratani 2006; Eboh 2005; Jackson 2006; Kuba and Lentz 2006) such a distinction drives subsequent customary laws regarding descent, belonging, and attachment to groups and lands. Such descent laws are then used to exclude outsiders or restrict in certain ways their rights to land. 'First-comers' in this context are believed to have almost ultimate legitimacy in a customary sense, to rights to land. In many cases this concept provides the basis for those in the 'first-comer' group to make laws affecting the transfer of land, inclusion and exclusion of others, and what rights various segments of local inhabitants have and do not have; such as the right to build houses, farm, plant trees, and bury the dead. In some cases the first comer group only includes a particular lineage (descendents of the founders), but in other cases it can be extended to include an entire ethnic group. The fieldwork noted that while the first-comers refer to the deeds of their ancestors as the legitimizing property constituting acts (discovery of the land in question, settlement or its conquest, or pacts with the gods or spirits, etc) late comers can also claim land by such acts (usually by clearing land, albeit the claim is weaker). Such acts legitimize, at least in the mind of those engaged in such acts, occupation, claim, and the right to control the activities of others on the land in question. More broadly, first comer - late comer aspects of claims to land in a variety of constructs are fairly widespread, figuring prominently in issue of ethno-nationality (Engerman et al 2004), migration (Landau 2006), autochthony and colonization (Ceuppens 2006), history of landscapes (Russell 1997), and identity (Herb and Kaplan 1999).

The second postulate is the customary belief that land cannot be subdivided or inherited privately, and that lineage lands belong to the dead, living, and unborn. In some locations this is stronger than others, and in an increasing number of locations it is re-emerging as a significantly strong 'invoked law', as it is elsewhere in Africa (e.g. Geschiere and Jackson 2006; Eboh 2005; Leynseele and Nebinck 2009; Fay 2009). Under this arrangement, land rights are vested in communities and are prohibited from sale. The 'community' may be families, a tribe, a clan, or villages. The head of the community then decides the basis for allocating land to community members (also Kollie 2006). Land that has been gained or allocated to lineage families is generally held by them in perpetuity, or at least internal to the lineage and chiefdom. ${ }^{3}$

3 Such a right of holding however does not traditionally include the right to alienate land, or hold it privately (see for example, Bropleh 1989).

$$
-6-
$$




\section{State sponsored customary law}

A significant aspect of the institutionalized separation of tenure systems in the country was the delimitation of 'state sponsored' customary law. This comprised certain subsets of customary law that became state sanctioned, supported, controlled, altered, and formally legitimized. This officially recognized customary law deviated from indigenous laws and in particular how they operated, to the degree that there existed competition between state sponsored and indigenous customary tenure and laws (Bruce 2007). For example the fieldwork revealed that a 'clan' in state sponsored customary law was not based on the idea of lineage as it existed in indigenous customary law, but was instead a geographic administrative area. As a result, the operative notion of clan in much of the interior eventually changed into a geographical area with a kin aspect. However in many locations there seemed to be little correspondence between the geographic area under the state sponsored definition of clan area, and the lineages' customary idea of traditional lands.

The government sought to ensure that state sponsored customary law would govern 'natives', while statutory law would govern Americo-Liberians, missionaries, and immigrants; although again 'natives' were subject to statutory law. From the fieldwork it was noted that this historical institutionalized divide was a primary source of subsequent tensions and acute problems (described later). The primary law articulating state sponsored customary law with regard to land, was the lengthy and substantively very dated 'Law and Regulations Governing the Hinterland'. Also important however, to setting this domain of law against others, was what was defined by the state as non-sanctioned and illegal customary law, together with customary laws which were simply ignored or loosely tolerated.

There were also a number of customary law-making institutions, which were not sanctioned by the state, and depending on the institution, were either prohibited or partially controlled. The Law of the Hinterland allowed some Poro and Sande secret societies as 'cultural societies', albeit under some control. ${ }^{4}$ Specifically noted as 'unlawful societies' were six other secret societies and all societies of a political nature. ${ }^{5}$ But because land tenure is always political this greatly aggravated the relationship between state sponsored customary law and indigenous customary law.

${ }^{4}$ For example permission was needed from the District Commissioner prior to their establishment (GoL 2001, article 68).

5 The six illegal societies are: the Human Leopard Society, the Negee Society, Suska, Toya, Kala, and Uama-Yama. 
As well, 'house palavers' in which disputes between extended family members are resolved by the oldest males, were not state sponsored and essentially ignored in statutory law (ICG 2006).

\section{ad hoc land and property norms}

Different from indigenous customary law which develops over considerable time, ad hoc land and property norms, as defined here, can emerge over a much shorter period in reaction to a combination of: confusion about laws, lack of enforcement, inequity (in both formal and customary law), and a variety of other land problems. The result is a reluctance to follow tenure rules that others are not following, and a hence a search for alternative 'normative orders' (e.g., Merry 1988; Griffiths 1986). Such informal 'legalities', while somewhat similar to what Plunkett (2005) calls informal 'micro rule of law systems' for postwar scenarios, and what Moore (1973) describes as 'semi-autonomous social fields' for stable settings, are different in that they comprise a variety of relatively quickly constituted alternative approaches to acquiring, (re)establishing, securing, defending, and proving rights and claims to property, land, homeland, and territory during unstable socio-political conditionsin Liberia's case the years leading up to the war. Their derivation parallels the general fracturing of society into smaller communities of shared experience, dislocation, and disaffection during times of considerable stress, instability, and state malfunction. In such a situation, ad hoc land and property norms that are incompatible, opposed, or in aggregate add confusion, confrontation and tenure insecurity, can significantly aggravate the socio-legal space of land tenure.

In Liberia the fieldwork found that the increasing instability of both customary and formal law prior to the war resulted in the emergence of a variety of aggressively pursued ad hoc norms tied to specific groups, which facilitated the claim, acquisition, and protection of lands. These groups were often opposed to each other and included: disenfranchised rural youth (with large numbers becoming combatants); dislocatees and squatters unable to access land or deprived of their lands; women's groups; specific ethnic groups and their subdivisions; opportunists claiming access and exploitation rights to land-based resources such as timber, rubber, and alluvial mineral deposits; opportunists in government able to access and alter land records; landholders acting to sell land and property held in fee simple multiple times; and chiefs and elders acting under the auspices of state sponsored customary law together with bribes, to sell customary land to outsiders, and coercively extract land and labor from rural youth or prevent land from being allocated to them. As well there was an adherence of certain groups to forms of Islamic law, particularly in the northeast of the country, in this case not as an ad hoc norm, but rather a readily available alternative. 


\section{Patterns of Socio-Legal Interaction}

Within Liberia's pre-war socio-legal space, there existed four primary patterns of interaction with regard to the sets of land rights 'legalities' that were most problematic: separation and isolation; ambiguity and confusion; the emergence of ad hoc land and property norms; and customary tenure versus statutory and state sanctioned customary law. While certain aspects of these patterns are also present in other countries, in Liberia all aspects of these patterns were present together, and were responsible for the creation of acute and volatile tensions in land tenure, which in aggregate contributed significantly to the onset of the war. This section describes these patterns, how they came about, and how they operated prior to the war to become explosive.

\section{Separation and isolation}

A primary relationship between law and society in the common law legal tradition (and many others, including customary traditions), operates through mutual exposure and the legal and societal change that occurs over time as a result of this exposure, so that law serves and is connected to society as it changes (e.g., Delville 2003; Andre 2003; McAuslan 1998; Platteau 2000). The fieldwork found that this is important to the Liberia case in two ways. First, the purposeful and maintained separation and isolation of formal and customary tenure, and second, the failure of Liberian formal legal institutions to update statutory law. Thus while there were distinct statutory laws for treating Americo-Liberians and indigenous Liberians separately, because the two groups did in reality interact 'on-the-ground' over issues of land, how this interaction occurred in the absence of statutory constructs relating to the interaction was crucial to the effect of law on Liberian society.

\section{(a) statutory - customary separation and isolation}

Current understanding regarding the disconnect between formal and customary land tenure in the developing world holds that the 'adaptation paradigm' is a significantly important way forward in the co-adaptation of the two systems (Bruce and MigotAdholla 1994). This co-adaptation occurs over time and involves not only the recognition and accommodation of customary ways by formal law, but the evolutionary transformation of customary law as well, in reaction to interaction with formal law. In a number of developing countries the exposure and influence between tenure systems is encouraged, is significant, and serves to bring new ideas, 
innovation, and adaptability to problems pertaining to customary and statutory interaction, land laws, and tenurial situations. ${ }^{6}$ In pre-war Liberia however the two systems were acknowledged to be distinct (not a real problem in itself, as this occurs in many locations in Africa) and that they were to be kept separate and not interact (the real problem). Thus there was little borrowing of ideas, issues, logic, experiences, methods, etc., (co-adaptation) over time between the two tenure systems in a legally progressive sense. Bruce (2007) notes for Liberia specifically that " $[\mathrm{t}]$ he failure to process customary land law disputes in the courts has important and negative implications for the evolution of customary land law. In other common law jurisdictions in Africa, customary rules have been reviewed and groomed by the courts for absorption into a larger body of common law. There has in Liberia been no such process". The fieldwork revealed that instead the opposite occurred. As opposed to forms of customary and formal law becoming integrated, they were set against one another, and this is quite different than in other African states. For example, the both the 'Laws and Regulations Governing the Hinterland' revised 2001, and the 'Rules and Regulations Governing Local Government Officials' were revised toward the end (Hinterland law in 2001) and after the war (Local Government Officials law in 2005), but because of the lack of exposure to customary laws, they are largely unchanged from their previous versions, thus retaining highly discriminatory aspects of law that were known to be connected to the cause of the war from the customary perspective. The result of such mutual isolation was an ongoing pluralism in a divisive way that generated and aggravated disputes as participants in both tenure systems interacted with each other over land access, claim, control, and exploitation. Thus the institution of 'state-sponsored customary law' in Liberia, and its intention to replace indigenous customary law, together with the purposeful isolation between indigenous customary and formal tenure, explicitly did not allow for indigenous customary law to penetrate and influence statutory law, or the reverse.

The fieldwork noted that what made this lack of exposure increasingly volatile over time for Liberia was that there were areas of very problematic and unresolved contradiction between indigenous customary, state sponsored customary, and formal law. The Constitution, the Hinterland Law, and the Public Lands Law are three examples where fundamental customary concepts regarding 'first comers,'

${ }^{6}$ For example Delville (2003) observes in several countries (Rwanda, Ivory Coast, Benin, Senegal) the infiltration of formal-like evidence (various forms of informal documentation) and procedures into customary land law that attest to land transactions (also Andre 2003). And there have been a number of cases elsewhere in Africa of the hybridizing of formal and informal land tenure systems, with significantly positive results in integrating the two (e.g. Bruce 2007; Maganga 2003; McAuslan 1998; Okoth-Ogendo 2000; Platteau 2000; Toulmin and Quan 2000). 
inalienability, property constituting acts, group membership, and boundary, ${ }^{7}$ were violated, with no institution, legal construct, or mechanism able to legitimately reconcile contradictions. Especially problematic were provisions within laws (regarding public lands, ownership of forests, the hinterlands), that claimed land belonged to the state, when such lands had clearly been occupied and used for very long periods of time under customary law. Such claims were a primary source of the tensions that contributed to the war (Bruce 2007). The Land Law of 1956 for example primarily attended to Americo-Liberian settlers in areas they occupied. All other land in the interior was, and continues to be, primarily occupied by indigenous Africans under customary land tenure, but is legally considered the property of the state and therefore public land (World Bank 2007). At the same time indigenous, non-Christian Africans were unable to use the Land Law themselves and the customary courts and their chiefs could not hear a case to which a 'civilized' person was a party (ICG 2006).

While Liberian statutory law acted to keep formal and customary tenure separate, those operating within customary tenure also acted to keep the two distinct, albeit for different reasons and in a different way. The fieldwork revealed that there existed significant resistance by those following customary tenure to the discriminatory statutory laws and practices (including state sponsored customary law). This acted to restrict the penetration of potentially valuable aspects of formal law into customary law. For example, the ongoing use of 'trial by ordeal' (described later) and 'invoked law' regarding return to the lineage of previously sold land, reveals a lack of exposure to what statutory laws are about. And while Poro secret societies were of some utility for land tenure including enforcement of decisions, at the same time the secret nature of these societies presented a significant constraint to the 'back and forth' exchange of information, ideas, and legal innovations necessary for customary tenure to evolve. And because membership or participation in other secret or political societies, ${ }^{8}$ and customary laws and institutions that were deemed illegal

7 'Soap trees' are the primary boundary marker for the customary sector throughout Liberia. The tree doesn't grow by itself, but must be planted. It does not seed, but puts up a number of trunks from one root system, creating a stand of trees. According to smallholders it is also accepted by formal law as evidence of a boundary location, and therefore ownership - although it is not specifically noted in formal law. Other terrain features are also used for customary boundaries: rivers, hills, etc. but these do not carry the evidentiary weight that soap trees do.

${ }^{8}$ The connection between the illegality of political societies, and the reality that land tenure is always political (Bruce and Migot-Adholla 1994) contributed to driving customary tenure activities into a hidden, and isolated domain of customary interaction. 
could be severely punished, including with imprisonment (GoL 2001, article 68), this encouraged their secret nature, their resistance to formal law, and their operation in isolation.

An additional factor acting to keep customary and formal tenure systems separate was the capacity of the formal legal system. The common law tradition in Liberia allowed judges to consider a broad range of sources in making legal decisions, including testimony and use of witnesses regarding how customary law works. In this regard there was applicability of customary law in statutory courts (also Bruce 2007). However in practice the profound failure of these components of the legal system to build a known body of customary - formal law interaction contributed significantly to their isolation. This was in part due to the low capacity of the formal legal establishment over time, along with its rigidity and over-formalistic notions of law. This deterministic mindset was, prior to the war, unwilling to receive input from the customary sector in terms of legal development of the country. Integrity of statutory law was, and continues to be, valued over 'law and society'. Contributing further to this problem, was the lack of operating lower courts; the distance between such courts and most rural or town inhabitants; and the lack of literacy, knowledge, and finances needed to file cases. As well the strong American ties, and prolonged organizational and institutional privation in successive governments made importing laws from elsewhere easier than developing Liberian-specific laws able to effectively embrace the interface between customary and statutory law in land tenure.

\section{(b) received and outdated formal law}

In the Western legal tradition, the role of legal journals or national law reports serve to inform the development of statutory law as an ongoing exercise (e.g., McAuslan 2003; Bruce 2007). This occurs by making known to lawyers, judges and the lawmaking process in general, what is important to society and how to address these. The lack in Africa however of "a national legal literature of some intellectual depth and maturity" (McAuslan 2003, 53) has both hindered the development of the relationship between laws and social realities (including customary law), and instead has continued or enhanced the influence of European and American law (McAuslan 2003). The fieldwork revealed that there was little attempt in Liberia at localization of these laws. Particularly relevant in Liberia's case, is McAuslan's $(2003,61)$ work, which concludes that for Anglophone African countries "the influence [of received law] has grown since independence; with the collapse in so many countries of a system of national law reports, judges rely on precedents from English and South African law reports which continue to be received in the law court libraries in lieu of anything else". In Liberia's case The Liberian Law Journal started publishing only 


\section{LAND AND LEGAL PLURALISM IN PRE-WAR LIBERIA \\ Jon D. Unruh}

in 1965 (143 years after the country was founded), stopped publishing from 1970-1974, resumed for a few issues, stopped again, published once more in 1986, then stopped permanently due to the problems developing in the country, and has yet to resume after the war.

As an example of the large role of received law in Liberia, reference is made in the Public Lands Law (GoL1956, article 90) to the government held right of 'escheat', which is the "reversion of property to the state in consequence of a want of any individual competent to inherit" (Black 1991). The definition of escheat focuses on the 'competent individual' as opposed to a group, able to inherit land. The fieldwork noted however that rural land in the Liberian interior is in most cases tied to groups and not individuals, with indigenous individuals unable to inherit land in the individualized Western sense. Instead land is tied to the lineage and access to it by lineage members is subject to clan, Paramount Chief, and elders' prescriptions. In the Public Lands Law the procedure for reclaiming land back from the government that it has taken over via the right of escheat is also focused on the individual, and assumes a good deal of literacy and financial resources. 9 Thus because customary groups do not pursue inheritance based on the individual, this aspect of the law is unworkable, goes against customary concepts of the group - land relationship, and resulted in loss of land and a source of grievance.

\section{Ambiguity and confusion}

From the fieldwork it emerged that the pervasive ambiguity and confusion on the part of both customary and formal tenure participants that was generated by the legal regime in Liberia prior to the war had a primary impact on tenure security. In a numerous of areas in the country customary owners are so insecure that they prohibit renters from planting trees or making other investments in land, believing that these will lead to claims. Widespread insecurity also turned many people away from adhering to either formal or customary law when neither provided clarity or effective tenure security. At the same time such ambiguity was an opportunity in that, in such a volatile, socio-politically unpredictable environment as pre-war Liberia, ambiguity was a strategy employed by some to acquire or preserve tenuous rights of land occupation, ownership, and use. Chiefs used the ambiguity and uncertainty created by state sponsored customary law and its competition with indigenous customary law to acquire large amounts of land and free labor that would

\footnotetext{
${ }^{9}$ Financial resources are necessary because the "deed shall be delivered only after the claimant shall have refunded to the Government the amount of any commission paid to the County, Territorial, or District Attorney on the escheat of the property" (Public Lands Law 1956e).
} 
not have been possible otherwise. Ambiguity was also quite valuable for opportunists operating within formal law seeking to obtain or retain land and property fraudulently, or sell the same land multiple times. Chabal and Daloz (1999) comment at length on the utility of such ambiguity and disorder as a tool elsewhere in Africa.

While there was a breadth of ambiguity-generating sources in statutory law regarding land rights, two laws were particularly problematic. The Liberian Constitution articulates the division between customary law and statutory law generally, but then refers specifically only to 'property' in the formal private property sense (GoL 1986), thus apparently applying only to those not from rural native areas. The result was to leave in an indeterminate state the ultimate, final rights of those from the interior. Such ambiguity acted to allow a wide range of manipulations, expropriation, and other conversions of 'non-private' holdings into private holdings; a conversion which aboriginal inhabitants were themselves unable to participate in.

Significantly ambiguous in the Hinterland Law from the customary perspective, was the term and concept of "adequate area for farming and other enterprises essential to the necessities of the tribe" [emphases added] (GoL 2001, article 66). "Adequate area' was also mentioned in Article 83 of the same law regarding the "Delimitation of tribal reserve" in the context of the need for a demarcation of an "adequate area for farming purposes of tribesmen before any land within the Territory of a Chiefdom shall be available for private purpose or grant of any kind whatever" (GoL 2001, 43). 'Adequate area' in both articles however was left undefined with regard to how such an area was to be determined, by whom, and what the 'essential' uses would be. The law did not include a 'definitions' section common to many laws in Anglophone countries. Nor did it refer to what a customary or tribal definition of 'adequate area' and 'essential' might be, how much land would be needed, and most importantly did not connect with local community or tribal boundaries that already existed. Not bringing the customary boundaries of chiefdoms already in existence into the definition of 'adequate area' or how this was to be determined, conflicted with customary concepts of 'early arrival', 'property constituting acts', and the 
inalienability of land, evidence, ${ }^{10}$ and boundary demarcation. This set up a confused, aggrieved, and conflicted situation regarding the boundaries of tribes, ethnic groups, and lineages. It also allowed for the definitions of 'adequate area' and 'essential' to be played with, to the advantage of one or another parties involved or interested in the delimitation exercise. The outcome was (and continues to be) confusion about definitions, and how such areas were determined. There was also a good deal of ambiguity about what rights were and were not included in a concession. Particularly important in this regard was the confused understanding about the right to exclude others (local communities) from a government issued concession. Complicating the concept of 'adequate area', article 66 of the Hinterland Law stipulated that such an area also depended on "whether or not they [the tribes] have procured deeds from Government, delimiting by notes and bonds [likely meaning 'metes and bounds'] such reserves..." (GoL 2001, article 66, p. 37). However, how the possession of, or the procedure for obtaining such deeds was to intersect with 'adequate area' was not described, allowing further ambiguity into the overall problem. Additional ambiguity and confusion prevailed in locations with a mix of ethnic and religious populations. In these areas there existed ethnic and Muslim 'governors' who as local authorities appointed by and operating under the Ministry of the Interior, were empowered to adjudicate customary disputes for inhabitants of the same religious or ethnic group (also ICG 2006; GoL 2005). The fieldwork revealed that this was despite the existence of locally legitimate customary institutions and authorities engaged in the same tasks.

Such ambiguity, while having utility to statutory officials to determine the status of specific areas using a wide variety of arguments, interests, and criteria, also resulted in deep and volatile animosity and tenure insecurity in the customary sector. As Bruce (2007) notes, a primary tension in statutory land law in Liberia is that there existed provisions protecting customary land rights, while different provisions facilitated the transfer of the same land to outsiders as public land. Whether such ambiguity was purposeful, for example in the derivation of the Hinterland Law, or its emergence inadvertent due to low capacity in legal drafting at the time, the outcome provided considerable 'room for maneuver' on the part of individuals knowledgeable and able to use the instruments of the state to pursue definitions in

10 Customary evidence in land disputes and claims includes, witnesses, elders called to indicate where a boundary is located, tombs and graves, trees, special landmarks such as specific rocks and other terrain features, which are then connected to 'stories' regarding the human - land interface over time. The stories are essentially the connection of history to parts of the physical landscape. The story must be tied in some way to the landscape to be useable customary evidence. So that if several people have the same story, connected to the same landscape, then that becomes powerful evidence in the customary domain. 
their favor, with no customary consultation. Such 'ambiguity as tool' was a frequent outcome of Liberian laws dealing with land and property, and resulted in significant grievance in the intersection of customary and formal law.

\section{The emergence of ad hoc land and property norms}

While the creation of the space for opportunism was one result of the tenurial confusion and ambiguity in Liberia, one of the more serious disruptive outcomes was the strong disincentive for rural native inhabitants to continue to participate in their own customary land laws that others (outsiders) were not following. While in other countries this can act to encourage customary inhabitants to use formal law, in Liberia this was not possible, leading to considerable instability in customary law. This contributed to the breakdown of customary laws and institutions regarding land, widening further the space for opportunism and driving the search for alternatives by rural inhabitants, particularly violence as a means to defend claims, resolve disputes, and acquire land. This search for alternatives led to the emergence of local, informal, ad hoc norms regarding aspects of land tenure. One example was the disillusionment of the rural youth with regard to the use of state sponsored customary law allowing chiefs to acquire and sell lineage customary land that otherwise would have gone to the youth. This disillusionment was pervasive, deeply aggrieved, and created an alternative 'legality' involving youth and violence.

A different ad hoc land and property norm that emerged from the interaction of customary, state sponsored customary, and formal law, had to do with a combination of 'woman damage', labor, and land. Land and marriage are intertwined in rural Liberia, and both were intensively controlled by customary elders (Richards 2005). To gain access to clan lands, a young man needed be in good standing with the elders who rule the descent group. There existed in the Hinterland Law (including the current revised version), two articles (article 54, Costs, fees, and Taxes; and article 55, Martial cases) which contained an array of fines for 'woman damage' 11 (GoL 2001). This aspect of state-sponsored customary law legally supported the derivation and maintenance of an ad hoc norm pursued by elders prior to the war, regarding purposefully seeking 'woman damage', and hence land and labor via the resulting fines. Richards (2005) describes this feature of rural life as a particularly important factor contributing to the war. Essentially the practice entailed the wife of an elder, being forced to 'call the name' of an accused male youth, thereby confessing to an extramarital affair. The accused male was then heavily fined and

11 'Woman damage' refers to extramarital relations, with the accused male being fined. The new inheritance law outlaws such damage seeking, thus constituting a contradiction with the Law Governing the Hinterland. 
this converted to a labor obligation. The outcome was that those indebted were then unable to acquire land themselves and engage as a peer in customary life as they came of age. Apart from 'woman damage' many young men were heavily fined by elders for petty or other false charges and coerced to work off such fines with labor on the farms of elders, again preventing acquisition of land by younger men. This form of ad hoc norm became acutely exploitive prior to the war, and was used to accumulate land and labor for plantation development (also Davis 2007). This was perhaps one of the most problematic aspects of ad hoc land and property norms in Liberia, and set the youth against the male elders over issues of land and labor. Such land in-access by a younger generation that was intended to shunt them into labour and away from land also pushed them into militias (Richards 2005). ${ }^{12}$

Largely in response to the above, the re-emergence of the 'inalienability of land' as a customary legal concept manifested itself in Liberia by younger members of lineages calling into question the 'right' of their elders or ancestors to have transferred land to outsiders, including sale, leasing, concessions, tribal deed issuance, etc. (Richards et al 2004; Kuba and Lentz 2006). The fieldwork indicated that the ad hoc norm associated with this re-emergence, was that younger lineage members began to nullify such transfers themselves. This was strengthened by the increasingly popular norm that land transfer to outsiders was always revocable by the traditional landowning lineages (also ICG 2006). This is thus an example where the emergence of one ad hoc norm gave rise to another opposed norm.

Customary tenure versus statutory and state sanctioned customary law: tension and competition

\section{(a) discriminatory pluralism}

Significant animosity was generated in Liberia from a history of discriminatory land laws and policies in a pluralistic context. The first article of the Local Government

12 Such an emergence of generational, land related ad hoc informal norms and groups connected to land and armed conflict is not isolated to Liberia. While present elsewhere in West Africa (Richards 2005) it is also present in Darfur, Sudan, with the emergence of the Shabab, an extreme pro-rebel youth group, which actively acts violently against their own elders for perceived transgressions. Among the top three conditions for the Shabab to be able to negotiate with the Sudanese government over an end to the conflict, expelling those whom have settled on land stolen from displaced farmers, is nearly as important as disarming government militias and prosecution for war crimes (Macfarquhar 2008). 
Law drew a distinction between the 'county area' and the 'hinterland.' The county area included all land extending from the coast 40 miles inland, and 40 miles from the Mano and Cavalla rivers. The hinterland included the area beginning at the eastern boundary of the county area and extending to the national borders (GoL 1972, article 1; GoL 2001, article 1). This separation was important because different laws applied to the different areas. Such a purposeful form of spatial legal pluralism was important in the institutionalization of the separation between 'native' areas and the rest of the country. However this geographical distinction is arranged in formal law as the county area continually expanding against a contracting customary area, as land is acquired via the statutory tenure system, and in particular via state sponsored customary law. And while there was a requirement for obtaining the permission of indigenous authorities in order to proceed with land acquisition under fee simple, this was frequently not honored (Bruce 2007). Conversely however the research revealed that there was no mechanism other than violence for land to move back under customary control.

The Liberian Public Lands Law (GoL 1956, article 53) enshrined explicitly the division between those who were deemed 'civilized,' and those who were not, in a land tenure context. The law articulates the procedures for acquiring tribal lands in fee simple for those deemed 'civilized' in a separate article (GoL 1956, article 30) from that which applied to indigenous inhabitants once they became civilized (GoL 1956 article 53). As an indication of the discriminatory character of this divide, it was not only more difficult to obtain land in fee simple for 'civilized aborigines' than Americo-Liberians, but it was also more difficult for 'civilized aborigines' than it was for immigrants (GoL 1956, articles 50, 51). For Americo-Liberians there was no requirement for erecting a structure or bringing farmland under cultivation prior to receiving a deed in fee simple, as there was for immigrants and 'civilized aborigines,' nor was there a stated limit on the area of land that could be purchased (GoL 1956, articles 53, 30, 50, 51). Immigrants to Liberia could receive ten acres of farmland if single, or 25 acres if married. From this they needed to bring at least two acres under cultivation if farmland (type of crops unspecified), and if a town lot, needed to erect a house meeting specific conditions (GoL 1956, articles 50, 51). There were no requirements for immigrants to 'become civilized' prior to obtaining land in fee simple. Indigenous inhabitants however, were required to 'become civilized,' were only entitled to the same amount of land as immigrants, but with the added stipulation that at least a quarter of the land needed to be brought "under cultivation by planting coffee trees, palm trees, rubber, cocoa, or other trees or plants bearing marketable products" (GoL 1956, article 53). Thus compared to immigrants, more land needed to be brought under cultivation ( 2 out of 25 acres for married immigrants, vs. 6.25 out of a 25 acre allotment for married 'civilized aborigines'), but additionally for indigenous inhabitants the land needed to be planted in "marketable products" and preferably tree crops. The Hinterland Law further states 
that fines can be imposed on 'tribesmen' for not planting crops for market and for not taking such crops to market. To have both settlers and immigrants be advantaged over indigenous Liberians in terms of obtaining and using deeded land, engendered significant animosity among the latter, particularly given that all rural land to be obtained by these three categories of people, was initially indigenously held property.

Leasing land was an additional area of significant discrimination. Leasing (to foreigners) was provided for in the Public Lands Law, and could be pursued on public lands "not appropriated for other purposes" (GoL 1956, article 70). Here "appropriated for other purposes" indicates lands not already allocated in fee simple to another use, or used by the state, concessionaire, foreign mission or diplomatic post, or already leased by the state. As a result land customarily held was open to be leased via statutory law. Excluded from the article on leasing is the ability of customary individuals or communities to engage in direct leasing arrangements with foreign interests, or exercise a right of reversion subsequent to a lease. In the law, no reference is made as to what local communities might gain from such state appropriation of customary land for leasing, or any role of community permission for such appropriation.

A separate discriminatory issue was the way that the Local Government Law structured the administration of Counties and their subdivisions (Townships). 'Superintendents' were the highest ranking official of the counties and were appointed directly by the President, not elected or otherwise selected by the local population. Other locally elected county officials were subordinate to this position. The superintendent's duties included, among others, "investigate and settle, under the direction of the President, all difficulties between native tribes, and all matters appertaining to the aborigines not within the authority of the tribal chiefs" (GoL 1972, article 12). However The Rules and Regulations Governing Local Government Officials of the Political Sub-Divisions of Liberia, indicated that commissioners and superintendents were empowered to review all matters from the chiefdoms. As well, the corporate powers of each Township belonged to a presidentially appointed Commissioner. And the Commissioners "have the care of all public property in their respective townships" (GoL 1972, articles 80, 85). As well Townships as corporate bodies had the power to "take and hold real and personal property for the benefit of the township" (GoL 1972, articles 80, 85).

Wildlife and National Parks Act (1987) further perpetuated the divisive, discriminatory approach to local communities and customary tenure. Two sections within Chapter 5 in particular were most problematic. Section 29, 'Establishment of Game Reserves and Controlled Hunting Areas', stipulated that the Wildlife Authority "may by regulation declare any area or land: (a) a Game Reserve for the 
protection, breeding and sustainable production of wildlife; (b) a Controlled Hunting Area in which hunting is controlled in accordance with regulations as may be issued by the Authority" (GoL 1987, 10). Thus Chapter 5 put in the hands of the Wildlife Authority the power to simply declare rural land to be no longer accessible to local communities who may already claim, reside in, or use an area. No consultation, preexisting occupation, or compensation is mentioned. This is aggravated by Section 30 , item 1 in the same Chapter, which states, "[n]o person shall hunt or capture any wild animal or enter into, settle, camp, cultivate, cut or burn trees or other vegetation or disturb wildlife in any way in a Game Reserve" (GoL 1987, 10). Clearly no settlements or farming were to be allowed in Game Reserves which were declared to exist by the Wildlife Authority. Again no mention is made of current occupants or claimants.

The Natural Resources Law, Chapter 6 'Ownership and Development of Mineral Resources' (GoL 1999), describes opportunities for dispute resolution and other forms of redress. But these required literacy, significant financial resources, and knowledge of the formal legal system. While there was a list of the types of "[1]ands not subject to mining privileges" (article 146), the only customary land type listed are Poro (secret society) bush reserves, which are relatively small pieces of land. As well the article entitled, "Mining operation a public utility" (article 143) stipulated that because the mining industry is important to the development of the country, mining operations were considered a public utility and thus were justified in "the exercise of the power of eminent domain" (GoL 1999, 646). Thus like the Wildlife and National Parks Act, there was ample legal opportunity to obtain land already claimed by customary communities, with no consultation.

Concessions were a particular problem in Liberia. These were granted very freely prior to the war, but a great deal of land granted to concessions was never used. However local communities appear to have been nonetheless excluded from the entire concession area. Bruce (2007) describes an example where on one million acres granted in rubber concessions since 1926, less than 20 percent was ever developed.

\section{(b) chiefs: selection, courts, trustees of communal holdings}

Monrovia's control over the chieftain structure penetrated quite far into the functioning of customary life, including land tenure. While this control was variable, depending in-part on distance from Monrovia, a primary way this control was exercised was through selection of chiefs as an aspect of state sanctioned customary law. While the Local Government Law stipulated that chiefs (Paramount, Clan, and Town) were to be elected every four years, the Law Governing the Hinterland 
indicated that those who were able to participate in such elections was very narrowly defined. A Paramount Chief was to be elected only by the Council of Chiefs and Elders, and was subject to the approval of the President. A Clan Chief was to be elected only by members of the clan who were of legal age, and were owners of huts and not delinquent in their taxes. Town Chiefs were elected by the "paramount residents" of the village (GoL 2001, article 21). As well, in the case of death, resignation, or suspension of a chief, the Minister of Internal Affairs appointed an acting chief until an election was held (GoL 1972, Chap. 5, 22). Thus the laws were oriented toward a form of postcolonial indirect rule in which local chiefs did the state's work (via state sponsored customary law) by dealing with what were regarded as small, time-consuming tasks, including land cases. In return local chiefs received from the state broad powers within state sponsored customary law that allowed them to enrich themselves at the expense of local communities (ICG 2006; Richards 2005).

The connection between the state's involvement in selecting and supporting chiefs (and by implication influence in chief's courts), and the abuse of chiefly powers regarding land, labor, and marriage was significant. The government-created customary courts (under state sanctioned customary law) were administered by the Ministry of Internal Affairs. Thus Town Chiefs, Clan Chiefs, and Paramount Chiefs were responsible for original jurisdiction in customary law cases at different levels. ${ }^{13}$ The fieldwork found that such customary courts were widely seen as corrupt and lacking in objectivity, legitimacy, and confidence among the customary sector. As a result land disputes frequently came to be resolved by violence but also by 'trial by ordeal'. In Liberia the latter usually occurred with the bark of the 'sassywood' tree made into a form of poison, with the accused either drinking it, or having it poured into the eyes, or the poison applied to a heated machete and put to the skin. If the person died, was blinded or injured, then s/he was guilty. Use of sassywood was seen as impartial. The use of trial by ordeal became common prior to the war due to the crippled formal and customary legal systems. While trial by ordeal is a form of customary law, it is also authorized as part of state sanctioned customary law as long as the life of the individual is not endangered (GoL 2001, article 73). Use of trial by ordeal in land cases was commonly as a form of appeal, after dissatisfaction with a decision made by a chief. And while the Liberian Supreme Court found trial by

13 Town Chiefs administered dispute resolution proceedings in towns, Clan Chiefs adjudicated between towns, and final decisions in Town Chief and Clan Chief courts would be appealed to the Paramount Chief courts (ICG 2006). Town and Clan Chiefs could also transfer complex cases that could not be resolved, to the Paramount Chief courts. Final judgments in Paramount Chief courts could be appealed to district commissioners and superintendents and finally to the Ministry's Office of Tribal Affairs in Monrovia. 
ordeal unconstitutional in 1949, the Rules Regulating the Hinterland (including its 2001 revision) continue to authorize it. The Ministry of Internal Affairs, in violation of both the judicial decision and the Constitution, did (and continues to) license 'ordeal doctors' to perform the rituals (GoL 2001, article 1; ICG 2006).

A further problem in the Hinterland Law, and an additional source of grievance and discrimination, was item $b$ of article 66 which states that "this land interest [regarding adequate area] may be transmitted into communal holdings upon application of a tribe made to the government for that purpose"; and item c (same article) indicating that the "communal holding will be vested in the Paramount Chief and Tribal Authority as Trustees for the tribe" (GoL 2001, article 66, p. 37). The fieldwork found that these two items together created a significant tension between indigenous customary law and state sponsored customary land law. For land to be deeded as a communal holding it needed to be surveyed, with the survey attached to the 'adequate area' term, concept, and delimitation. There was (and is) considerable reluctance for customary community members to move forward with a communal deed application if they did not agree with the state as to the boundaries or quantity of land to be included, because such a deed would only support the state's definition and delimitation of 'adequate area'. On the other hand there was considerable willingness on the part of the Paramount Chief and 'Tribal Authority' to have an 'adequate area' transmitted to such communal holdings, because they were the trustees that the holding was then vested in. It was noted a number of times in the fieldwork that the descendents of such trustees had acted to have such communal land deeded entirely to them as individuals, based on the fact that their father's name was on the communal land document, followed by "et al". This latter arrangement was another ad hoc land and property norm that contributed to the volatile situation between state sponsored and indigenous customary law. This also fed the notion among younger rural inhabitants that the earlier transmission of land to "communal holdings' was not legitimate, and needed to be revoked, with such revocation itself emerging as an ad hoc land and property norm. This is thus another example where one ad hoc norm contributed to the derivation of another, opposed, grievance based, norm.

By the state making it lucrative for the chief (and associated elders) to engage in activities via state sponsored customary law that were opposed to the desires of local community members, a volatile tension was produced in which very different interests in land tenure were pursued by the leadership versus the wider community. There was little recourse against the chief or other elders with regard to abuses and exercise of prerogatives, outside of violence. 


\section{LAND AND LEGAL PLURALISM IN PRE-WAR LIBERIA \\ Jon D. Unruh}

\section{Conclusion}

The end to the war in Liberia has not brought an end to the volatile nature of the socio-legal space regarding land tenure in the country. Deep animosities and tensions over land have not been resolved by the signing of the peace accord, nor by the large military and civil affairs presence of UMNIL (United Nations Mission in Liberia), and the various donors present in the country (Unruh 2009). The land tenure problems in the country are still acute. Disputes over land are the "most explosive issue in Liberia today" (CGAR 2009, 8). The President of the country has "expressed fear that the issue of land reform, if not swiftly redressed by the government and its international partners, could crop up into another war in the country" (Daygbor 2007); and the Crisis Group Africa Report echoes this, indicating that land disputes could be a root cause of any subsequent insurgency (CGAR 2009). Land rights-related violence has continued to occur or has increased in different parts of the country (NC 2007; GOL 2006; Unruh 2009; CGAR 2009), and in some areas, progress achieved by UNMIL to enforce formal land laws, has been scuttled as people return to the illegal extraction of rubber, timber, and diamonds, as well as squatting and forced eviction. And Richards $(2005,587)$ indicates that, "[y]oung people without secure tenancy rights will continue to float in the countryside without stable social commitments, and thus remain vulnerable to both chiefs and militia recruiters" (also Corriveau-Bourque 2007). The administrative and judicial systems required to handle land matters in the postwar context, while initially underdeveloped, nonfunctional and overstretched, are improving, particularly with regard to the work of the Governance Reform Commission, which has recently established a Land Commission. And there is a profound lack of trained personnel to manage the property rights system and to adjudicate disputes (GRC 2007). As a result, presently between 75 and 90 percent of all cases in all statutory courts (probate, civil, criminal, appellate) are land and property related (Unruh 2009; GRC 2007).

What is needed in postwar Liberia is an appreciation of the historical and structural process by which land tenure in the country became increasingly aggravated and explosive. This is important because addressing land tenure in the postwar period will require more than simply a rework of statutory laws. It will in addition require a reformulation of the socio-legal relationship between statutory law, customary law and society that takes into account, 1) a needed corrective to the abuse by the urban elite and customary leadership that emerged from the interaction of state sponsored customary law with other sets of laws and norms, 2) the ongoing robust presence of ad hoc land and property norms which continue to take on new directions, 3 ) a much needed rework of the statutory legal environment that de-emphasizes 'integrity of the law' and places more emphasis on 'law and society', 4) a reinstatement of the Liberian Law Journal and greater priority given to customary law as a topic of 
examination, analysis, and legal recommendation, and 5) the derivation and institution of a form of 'customary law officer' similar to what exists in neighboring Sierra Leone, able to act as an interface between statutory and customary law.

The Liberia case is instructive in that it provides a setting to examine the socio-legal interactions involving land rights which can be a significant contributor to civil wars. In Liberia the interaction within the tenurial socio-legal space involved sets of land-related laws and norms that became set against one another over time in a mutually aggravating way. The roots of the problem are embedded in the country's history, legal capacity, and different forms of logic regarding rights to land, together with an emphasis placed on the non-interaction of these forms of logic. With no legitimate institution or authority able to resolve the resulting acute tensions, for many there appeared to be little opportunity for recourse to perceived prolonged injustice, other than violence.

\section{References}

ALLOTT, A.

1967 'A Report on the feasibility of research into Liberian customary law.' Liberian Law Journal 3: 83-100.

ANDRE, C.

2003 'Custom, contracts and cadastres in north-west Rwanda.' in T.A Benjaminsen and C. Lund (eds.), Securing Land Rights in Africa. London: CASS Publishing.

BANKS, P.

2007 'Issues paper on reforming Liberia's legal and judicial system towards enhancing the rule of law.' Governance Reform Commission, Monrovia: Republic of Liberia.

BLACK, H.

1991 Black's Law Dictionary, St. Paul, MN, USA, West Publishing Co.

BROPLEH, N.D.

1989 'Land tenure and land use policies. green revolution action plan, phase 1: 1990-1992, background support paper no. 1. Monrovia: Food and Agriculture Organization of the United Nations.

BRUCE, J.W. and S.E. MIGOT-ADHOLLA

1994 Searching for Land Tenure Security in Africa. Dubuque, Iowa: The World Bank and Kendall/Hunt Publishing Co.

BRUCE, J.W.

2007 'Insecurity of land tenure, land law and land registration in Liberia: a preliminary assessment.' Washington DC: The World Bank. 
CHABAL, P., DALOZ, J.

1999 Africa Works: Disorder as Political Instrument. Bloomington IN, USA: Indiana University Press.

CORRIVEAU-BOURQUE, A.

2007 'An environment for recruitment: power and marginalization in Liberia.' Montreal: McGill University Program for International Development Studies, Honors Thesis.

CGAR (Crisis Group Africa Report).

2009 'Liberia: uneven progress in security sector reform.' Crisis Group Africa Report No. 148, 13 January.

CEUPPENS, B.

2006 'Allochthons, colonizers, and scroungers: exclusionary populism in DAVIS, J. Belgium.' African Studies Review 49: 147-186.

2007 'Tree crop sub sector report.' Liberia Agriculture Sector Review, Monrovia DAYGBOR, J. and Washington DC: World Bank.

2007 'Land dispute - country's next war trigger.' The Analyst, Monrovia AllAfrica Global Media. Monrovia, 21 March.

DELVILLE, P.L.

2003 'When farmers use 'pieces of paper' to record their land transactions in francophone rural Africa: insights into the dynamics of institutional innovation.' in T.A. Benjaminsen and C. Lund (eds.), Securing Land Rights in Africa, London: CASS Publishing.

EBOH, S.O.

2005 Inalienability of Land and Citizenship in the African Context Frankfurt: IKO-Verlag fur Interkulturelle Kommunikation.

ENGERMAN, S.L.

2004 Land Rights, Ethno-nationality, and Sovereignty in History. London: Routledge.

FAY, D.

2009 'Property, subjection and protected areas: the 'restitution' of Dwesa-Cwebe Nature Reserve, South Africa.' in D. Fay and D. James (eds.) The Rights and Wrongs of Land Restitution: 'Restoring What Was Ours. New York: Routledge - Cavendish.

GESCHIERE, P. and S. JACKSON

2006 'Autochthony and the crisis of citizenship: democratization, decentralization, and the politics of belonging.' African Studies Review 49: 1-8.

GRC (Governance Reform Commission)

2007 The way forward: land \& property right issues in the republic of Liberia.' Governance Reform Commission, Monrovia: Government of Liberia' 
GoL (Government of Liberia).

1956 Liberian Public Lands Law, Monrovia: Vol III. Government of Liberia.

1972 Local Government Law, Monrovia: Government of Liberia.

1986 Right to Own Property. Article 22, Constitution of the Republic of Liberia: Monrovia: Government of Liberia.

1987 Wildlife and National Parks Act. Game reserves, controlled hunting areas and other protected areas, Chapter $V$. Monrovia: Government of Liberia.

1999 Natural Resources Law. Ownership and development of mineral resources. Liberian Codes Revised, Vol IV, Monrovia, Government of Liberia.

2001 Revised Laws and Administrative Regulations for Governing the Hinterland, Ministry of the Interior, Monrovia: Government of Liberia.

2005 Rules and Regulations Governing Local Government Officials of the Political Sub-Divisions of Liberia, Revised Edition, Ministry of Internal Affairs, Monrovia, Government of Liberia, 24 February,.

2006 Liberia Statement of Policy Intent for Agriculture. Ministry of Agriculture, Monrovia: Government of Liberia,

GRIFFITHS, J.

1986 'What is Legal Pluralism?' Journal of Legal Pluralism 24 :1-52.

HERB, G.H., KAPLAN, D.H.

1999 Nested Identities: Nationalism, Territory, and Scale. Boulder: Rowman and Littlefield Publishers.

HOHE, $\mathrm{T}$.

2005 'Developing local governance.' in G Junne and W Verkoren (eds.), Postconflict Development: Meeting New Challenges, Boulder: Lynne Rienner.

ICG (International Crisis Group)

2006 'Liberia: restructuring the justice system.' International Crisis Group Africa Report, Brussels No. 107.

2004 'Liberia and Sierra Leone: rebuilding failed states.' International Crisis Group Africa Report, Brussels No. 87.

IRIN

2007 Liberia: Donor Fatigue Threatening DDR Process. UN Office for the Coordination of Humanitarian Affairs.

JACKSON, S.

2006 'Sons of which soil? the language and politics of autochthony in eastern DR Congo.' African Studies Review 49: 95-124.

KOLLIE, J.

2006 'Report of the situation of land tenure in Liberia.' Rome: Food and Agriculture Organization of the UN.

KUBA, R. and C. LENTZ, C. (eds.)

2006 Land and the Politics of Belonging in West Africa. Boston: Brill Press.

LANDAU, L.B. 
2006 'Transplants and Transients: Idioms of Belonging and in Innercity Johannesburg.' African Studies Review 49: 125-146.

LEYNSEELE, von Y. and P. HEBINCK

2009 'Through the prism: the reworking of land resititution settlements in South Africa.' in D. Fay and D. James (eds.) The Rights and Wrongs of Land Restitution: Restoring What Was Ours, New York: Routledge - Cavendish.

MCCARTHY, N.

2007 Customary Land Use in Liberia: A Review of Supreme Court Decisions. Monrovia: IFPRI and George Mason University School of Law.

MAGANGA, F.

2003 'The interplay between formal and informal systems of managing resource conflicts: some evidence from south-western Tanzania.' in T. A. Benjaminsen and C. Lund, C. (eds.), Securing Land Rights in Africa, London: CASS Publishing.

MACFARQUHAR, N.

2008 'The scared sheiks.' The New York Times, December 21.

MARSHALL-FRATANI, R.

2006 "The war of "who is who": autochthony, nationalism, and citizenship in the MCAUSLAN, P.

1998 'Making law work: restructuring land relations in Africa.' Development and Change 29: 529-552.

2003 Bringing The Law Back In: Essays in Land Law and Development. MERRY, S. Burlington: Ashgtate Publishing Limited.

1988 'Legal pluralism.' Law and Society Review 22: 869-896.

MOORE, S.

1973 'Law and social change: the semi-autonomous social field as an appropriate field of study.' Law and Society Review 7: 719.

NC (National Chronicle)

2007 'In Firestone shooting: two security personnel wounded.' National Chronicle, February 19, Monrovia.

OKOTH-OGENDO, H.W.O.

2000 'Legislative approaches to customary tenure and tenure reform in East Africa.' Pp. 123-134 in T. Toulmin and J. Quan (eds.) Evolving Land Rights, Policy and Tenure in Africa. London: Natural Resources Institute.

PLATTEAU, J.P.

2000 'Does Africa need land reform?' Pp. 51-74 in T. Toulmin and J. Quan (eds.), Evolving Land Rights, Policy and Tenure in Africa. London: Natural Resources Institute. 
PLUMMER, B.

2007 'Land tenure: the neglected path to social security and reconstruction in Liberia Montreal: McGill University Program for International Development Studies, Honors Thesis.

PLUNKETT, M.

2005 'Reestablishing the rule of law.' in G. Junne and W. Verkoren (eds.), Postconflict Development: Meeting New Challenges, Boulder: Lynne Rienner.

RICHARDS, P.

2005 'To fight or to farm? agrarian dimensions of the Mano River Conflicts Liberia and Sierra Leone.' African Affairs 104: 571-590.

RICHARDS, P., S. ARCHIBALD, B. BRUCE, W. MODAD, E. MULBAH, T. VARPILAH and J. VINCENT

2004 'Community cohesion in Liberia: a post-conflict rapid social assessment. Monrovia: African Knowledge Associates.

RIDDELL, J. and C. DICKERMAN

1986 'Land tenure profile: Liberia.' in J. Riddell, and C. Dickerman (eds.), Country Profiles of Land Tenure: Africa 1986. Madison, WI: Land Tenure Center, University of Wisconsin, Madison.

RUSSELL, W.B.

1997 People and the Land through Time: Linking Ecology and History. New SAWYER, A Haven: Yale University Press.

2005 Beyond Plunder: Toward Democratic Governance in Liberia. London: Lynne Rienner Publishers.

TOULMIN, C. and J. QUAN, J.

2000 Evolving Land Rights, Policy and Tenure in Africa. London: Natural Resources Institute.

UNEP (United Nations Environment Programme)

2004 Desk Study on the Environment in Liberia. Nairobi: UN Environmental UNRUH, J. Programme.

2002 'Poverty and property rights in the developing world: not as simple as we would like.' Land Use Policy 19: 275-276.

2009 'Land rights in postwar Liberia: the volatile part of the peace process.' WILY, L. Land Use Policy 26: 425-433.

2007 So Who Owns the Forest: an Investigation into Forest Ownership and Customary Land Rights in Liberia. Brussels: Sustainable Development Institute/FERN. 


\section{LAND AND LEGAL PLURALISM IN PRE-WAR LIBERIA}

Jon D. Unruh

WORLD BANK

2007 Concept note Liberia: the role of land tenure in confronting the challenges of transition - a strategic plan for accelerating growth and investment in the urban and rural sectors. Washington, DC: World Bank. 